\title{
MABEL B. WESLEY ELEMENTARY
}

\author{
Wilma Rimes \\ Mabel B. Wesley Elementary School
}

\begin{abstract}
The Mabel B. Wesley Elementary School, in Houston, Texas, has had a school-wide Direct Instruction language arts curriculum since 1976, and has implemented other direct instruction programs and other programs based on related approaches in other subject matters. Eighty-four percent of the largely African American student body population qualify for free or reduced lunch. In spite of the sometimes severe conditions of poverty from which many of the students come, this school consistently outperforms other elementary schools within the Houston school district, including schools with students in the top SES. Through the use of Direct Instruction, students develop the foundation skills on which they can build many of the skills other programs assume students will acquire with no direct planning. They are able to move successfully from the structured learning environment of Direct Instruction to advanced lessons in thinking and problem solving and are also well prepared to handle less structured "student centered" environments. Comparison studies show Wesley students greatly outperforming matched minority schools in the state, and outperforming state norms for all schools except in grade 5 math, where scores were equal to state norms. On standardized tests, Wesley scores at or above national norms.
\end{abstract}

Wesley Elementary is in the Acres Home Community located on the north side ofHouston. Wesley is one of four schools in the Northwest Charter District which is one of the thirteen districts that make up the Houston Independent School District. Dr. Thaddeus S. Lott, Sr., is the Project Manager for the Northwest Charter District and Mrs. Wilma Rimes is the principal of Mabel B. Wesley Elementary School.

In 1975, many children at Wesley school were non readers or read one or two years below grade level. Many sixth grade students read on a second grade level, and a few were nonreaders. In searching for a means of improving reading skills, Dr. Lott, then the new Principal, visited a campus that was implementing the DISTAR (see Direct Instruction System for Teaching and Remediation, Carnine and Silbert, 1979) reading curriculum, developed by Engelmann (reported in Becker, Engelmann and Thomas, 1975a and 1975b). He was impressed by what he observed and began the implementation ofDISTAR in 1976.

The chart in Figure 1 shows the mean grade equivalent for third through sixth grades (the only grades tested prior to implementing DISTAR) in 19731974 and in the first years of implementation. Beginning in the Spring of 1977, first and second grade students were tested on the Iowa Test of Basic Skills. With the implementation of the DISTAR reading program an increase in grade equivalent scores was observed. (NOTE: Students are expected to show at least eight months

\section{AUTHOR'S NOTE:}

For further information please address correspondence to: Ms. Wilma B. Rimes, Principal, Mabel B. Wesley Elementary School 800 Dillard, Houston, TX 77091. 
RIMES

\begin{tabular}{|c|c|c|c|c|c|c|c|}
\hline $\begin{array}{c}\text { School } \\
\text { Year }\end{array}$ & $\begin{array}{c}\text { Kinder- } \\
\text { garten }\end{array}$ & $\begin{array}{c}\text { First } \\
\text { Grade }\end{array}$ & $\begin{array}{c}\text { Second } \\
\text { Grade }\end{array}$ & $\begin{array}{c}\text { Third } \\
\text { Grade }\end{array}$ & $\begin{array}{c}\text { Fourth } \\
\text { Grade }\end{array}$ & $\begin{array}{c}\text { Fifth } \\
\text { Grade }\end{array}$ & $\begin{array}{c}\text { Sixth } \\
\text { Grade }\end{array}$ \\
\hline $\begin{array}{c}1973- \\
1974\end{array}$ & $\begin{array}{c}\text { not } \\
\text { tested }\end{array}$ & $\begin{array}{c}\text { not } \\
\text { tested }\end{array}$ & $\begin{array}{c}\text { not } \\
\text { tested }\end{array}$ & 2.6 & 3.3 & 3.9 & 4.9 \\
\hline $\begin{array}{c}1976- \\
1977\end{array}$ & $\begin{array}{c}\text { not } \\
\text { tested }\end{array}$ & 1.8 & 2.8 & 2.9 & 3.9 & 4.5 & 5.3 \\
\hline $\begin{array}{c}1978- \\
1979\end{array}$ & $\begin{array}{c}\text { not } \\
\text { tested }\end{array}$ & 2.6 & 3.3 & 4.4 & 5.3 & 5.1 & 6.1 \\
\hline
\end{tabular}

Figure 1. Grade Equivalent Scores on Iowa Test of Basic Skills

growth for each grade level. The theoretical grade level at the end of first grade is 1.8.)

Based on this improvement, DISTAR reading was expanded each year until there was school-wide implementation. Wesley has continued to use DISTAR (now part of the Reading Mastery series, which now includes stories, literature, and a range of supplemental material) and has added numerous other Direct Instruction (e.g., Reasoning and Writing, Spelling Mastery) and similar programs (e.g., math and history) based on an equivalent rationale throughout its curriculum. Wesley also has a science laboratory as well as other facilities. While many other schools. constantly changed programs as educational fads shifted, Wesley School stayed with and perfected its program. The most recent and comprehensive research review on teaching reading from the National Institute of Child Health and Human Development (Grossen, 1997) validates the way that Wesley has been instructing their students for the last twenty years, stressing the importance of early teaching of phonics, explicit instruction in sound spelling correspondence, systematic teaching of regular sound spelling relationships, showing children how to sound out words, using decodable text stressing what has been taught, and using strategies to teach comprehension through interesting stories.

\section{Program Description}

Wesley has 1,082 children (93\% African American, 6\% Hispanic, 1\% White) enrolled in prekindergarten through fifth grade. Eighty-four percent of the population is on free or reduced lunch. The school day for the children runs from 8:00 a.m. until 3:00 p.m. and the teachers' work day is from 7:30 a.m. until 3:15 p.m., although most arrive early and stay late.

Wesley currently uses Reading Mastery (formerly DISTAR) as its core reading program. Reading Mastery initially emphasizes the acquisition and mastery of critical word attack (decoding) skills based on phonics. This is done in a direct, clear and straightforward fashion. Teachers present lessons to teach new skills, practice skills already learned, and apply all of these skills in the context of reading stories designed for this purpose. In addition, students read for comprehension. Typically, the majority of students have mastered the basic phonics and word attack skills in 


\section{MABEL B. WESLEY ELEMENTARY}

first grade and move on to instruction that emphasizes applying thinking skills and strategies to comprehend what they read. Throughout all instruction, students are actively engaged in the learning process by responding as a group or on an individual basis when called upon or by responding in writing. They receive instant feedback to confirm or correct their responses. Students actively practice the skills and strategies presented throughout the lessons. All students receive consistent daily practice and review in reading, writing, listening, and speaking.

Reading instruction also includes a basal reader and a wide variety of novels. The classroom and campus library offer children the opportunity to read and comprehend a wide range of books and other texts. Students participate in various incentive programs involving reading. High expectations for all teachers and students, combined with a program that makes it possible to reach these expectations, make Wesley a successful school. The students understand what is expected of them. They work hard and their self-esteem is obvious when they read aloud to you, share a story they've written, or explain a science project they have completed. The Principal and the Assistant Principal observe classes on a daily basis, check student performance and records, and provide teachers with the necessary materials and supplies. The Lead Teacher monitors student progress every day. These individuals provide in-service training if indicated. Additional support is provided by the instructional specialists and the reading teacher trainer from the Charter District.

Teachers are well prepared to meet the demands of teaching at Wesley. Staff development is an ongoing process. Prior to the opening of school, teachers new to the school receive pre service training. Throughout the year training is provided based on the needs of the teachers and students. Mentor teachers are assigned to all new teachers. There is an incentive program that addresses staff development and student performance. Based on guidelines from the state, the Houston Integrated School District (HISD) designates six full staff development days and six early release days. The dedication and commitment of all involved is evident upon entering the building. Teacher and student enthusiasm are evident throughout the school. The office and custodial staff strive with them toward a common goal.

\section{Evaluation}

The students in third, fourth and fifth grades are required to take the TAAS (Texas Assessment of Academic Skills) Reading and Math test every year. The fourth grade students also take the TAAS writing test. The TAAS is a criterion referenced test given in the spring each year. In May, 1996, Wesley tested 408 students in grades three, four and five. Their scores are shown in Figure 2. 


\section{RIMES}

\begin{tabular}{|c|cc|cc|cc|}
\hline GRADE & \multicolumn{2}{|c|}{ READING } & \multicolumn{2}{c|}{ MATH } & \multicolumn{2}{c|}{ WRITING } \\
\hline & \#Taking & \%Passing & \#Taking & $\%$ Passing & \#Taking & \%Passing \\
\hline 3 & 141 & 100 & 138 & 100 & & \\
\hline 4 & 146 & 82 & 144 & 84 & 145 & 100 \\
\hline 5 & 121 & 89 & 124 & 79 & & \\
\hline & & & & & & 145 \\
TOTAL & 408 & 90 & 406 & 88 & 100 \\
\hline
\end{tabular}

Figure 2. Scores on the Texas Assessment of Academic Skills: May, 1996

In addition, the students (K-5) at Wesley take the Iowa Test of Basic Skills, a norm referenced achievement test. A pretest is given in the Fall and a posttest is given in the Spring. Students are expected to show nine months growth. Their grade level scores are shown in Figure 3.

By comparison, in 1977 before the direct instruction program was implemented, grade equivalent core total scores on the ITBS were appreciably lower with fourth, fifth and sixth grade students, in particular well below 1996 levels (see Figure 1).

Wesley Elementary students in grades 3 and 5 were evaluated in a comparison study. This study compared Wesley with all HISD schools and with other statewide schools where the majority of students were African American, in Reading, Writing, Math and Total passing All Tests. These results are indicated in the graph in Figure 4. The scores were the percent of students meeting the Grade level standards on the Texas Assessment of Academic Skills (TAAS) test.

\begin{tabular}{|c|c|c|c|c|}
\hline $\begin{array}{c}\text { GRADE } \\
\text { LEVEL }\end{array}$ & READING & LANGUAGE & MATH & $\begin{array}{c}\text { CORE } \\
\text { TOTAL }\end{array}$ \\
\hline $\mathrm{K}$ & $\mathrm{K}-9$ & $\mathrm{~K}-7$ & 1.0 & K-9 \\
\hline 1 & 2.3 & 2.2 & 1.9 & 2.1 \\
\hline 2 & 3.0 & 3.3 & 2.8 & 3.0 \\
\hline 3 & 4.1 & 4.9 & 4.5 & 4.5 \\
\hline 4 & 4.8 & 5.7 & 5.5 & 5.2 \\
\hline 5 & 5.5 & 6.5 & 6.6 & 6.2 \\
\hline
\end{tabular}

Figure 3. Scores on the Iowa Test of Basic Skills: Spring, 1996 
MABELB. WESLEY ELEMENTARY
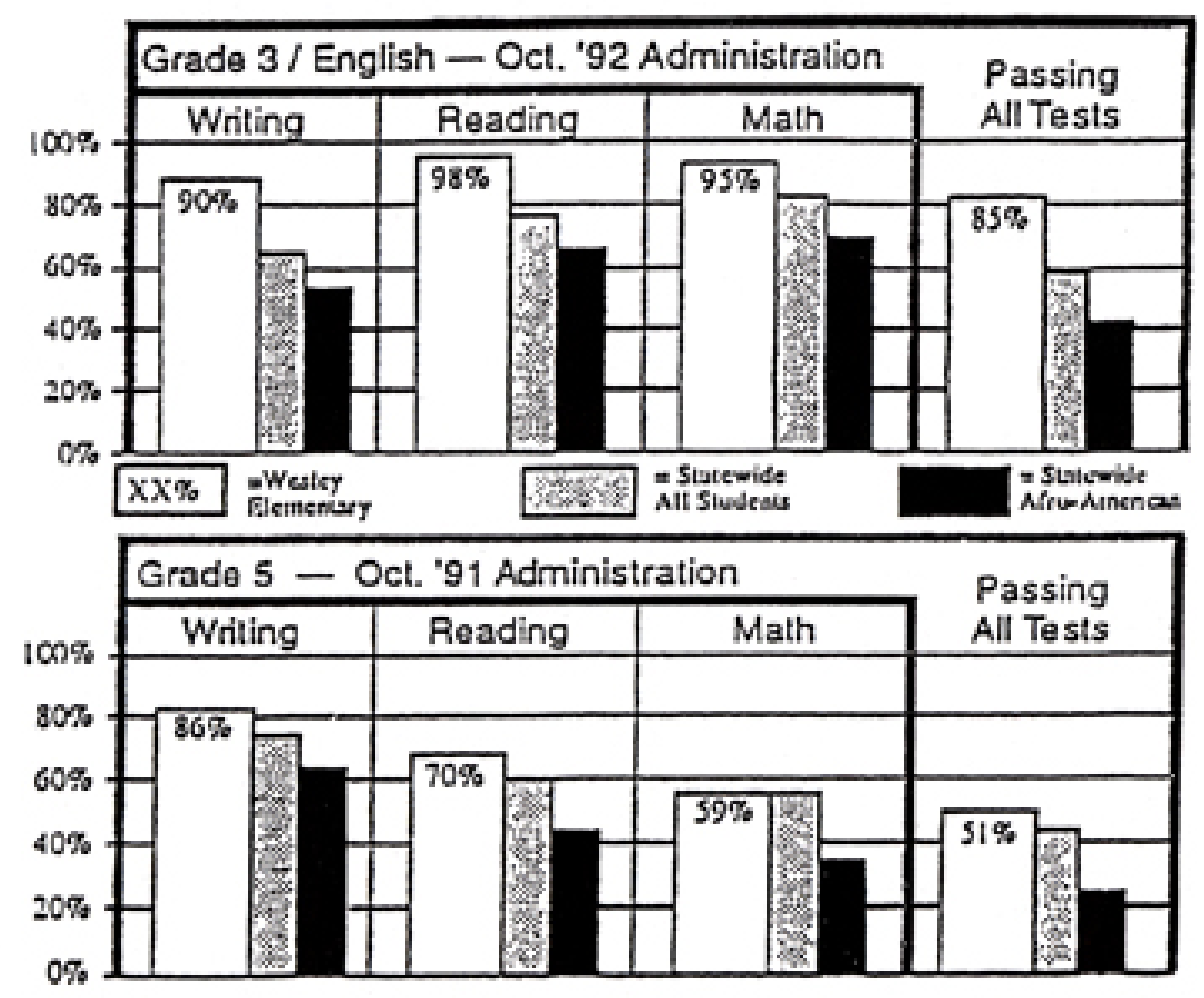

Figure 4. TASS Indicators Comparing Wesley to Students Statewide

TAAS Indicators Prove That Wesley Elementary's Approach Works. Wesley Elementary students in the Houston ISD consistently outperform their classmates statewide on testing programs-such as TASS-as illustrated in this chart. The statewide results for Afro-American students are listed for comparison purposes because Wesley's student population is primarily black. The heights of the bars illustrate the percentages of students passing TAAS, with the actual percentages listed for Wesley students. Information sources: Houston 1SD, Texas Education Agency. 


\section{RIMES}

It will be noted that in every area Wesley students surpassed both statewide scores and scores for other schools with mainly black students, except in 5th Grade math where Wesley scores and statewide scores were equal.

In another earlier comparison study in 1977-1980, Wesley School Vocabulary and Comprehension scores on the Iowa Test of Basic Skills were compared with 10 other HISO schools. These schools were selected as controls because each had at least $85 \%$ black enrollment, and each had more than $70 \%$ of the students on free lunch. It was felt these schools matched Wesley in racial and SES makeup.

Each year more Direct Instruction classes were added and by 1978 all students in grades 1-3 were using DISTAR. Thus, Wesley students scored somewhat higher than most other schools in 1977, the first year for which data are available. First and second grade ITBS data are not available prior to 1977. Results are presented by grade levels in Figure 5. Scores for control groups are averaged across schools.

Finally, it is interesting to note that out of 1082 students, only $7.1 \%$ are diagnosed as needing special education (district average is 16.7\%), and currently only 19 receive this instruction in a special education class, the others being mainstreamed with some resource room instruction.

Planning budgetary costs for implementation of a 01 curriculum depends on several variables, including the programs being implemented, school size, class size, and grades involved. Prior background determines the amount of training and monitoring needed. Staff development and training is the critical component of the model, and should include:

- Pre-service training teachers receive before they begin teaching direct instruction programs. An average of 10 hours per beginning level program.

- In-service training teachers receive outside their classrooms during the school year.

- In-class coaching and monitoring including observation periods, feedback and follow up to insure success.

Figure 6 shows the estimated cost for a class of 25 doing Reading Mastery. Costs of implementation are greatly reduced if inservice and in class services are provided by an exemplary district or school direct instruction teacher with training in 01 coaching techniques. 
MABEL B. WESLEY ELEMENTARY

FIRST GRADE

PERCENT OF STUDENTS AT OR ABOVE GRADE LEVEL ON ITBS

\begin{tabular}{|l|c|c|c|c|c|c|c|c|}
\hline & \multicolumn{2}{|c|}{1977} & \multicolumn{2}{c|}{1978} & \multicolumn{2}{c|}{1979} & \multicolumn{2}{c|}{1980} \\
\hline & $\mathrm{V}$ & $\mathrm{C}$ & $\mathrm{V}$ & $\mathrm{C}$ & $\mathrm{V}$ & $\mathrm{C}$ & $\mathrm{V}$ & $\mathrm{C}$ \\
\hline Control Schools, N=10 & 35 & 32 & 47 & 45 & 52 & 53 & 53 & 56 \\
\hline Wesley School & 45 & 62 & 90 & 97 & 90 & 92 & 98 & 97 \\
\hline
\end{tabular}

SECOND GRADE

PERCENT OF STUDENTS AT OR ABOVE GRADE LEVEL ON ITBS

\begin{tabular}{|l|c|c|c|c|c|c|c|c|}
\hline & \multicolumn{2}{|c|}{1977} & \multicolumn{2}{c|}{1978} & \multicolumn{2}{c|}{1979} & \multicolumn{2}{c|}{1980} \\
\hline & $\mathrm{V}$ & $\mathrm{C}$ & $\mathrm{V}$ & $\mathrm{C}$ & $\mathrm{V}$ & $\mathrm{C}$ & $\mathrm{V}$ & $\mathrm{C}$ \\
\hline Control Schools, N=I0 & 35 & 34 & 39 & 32 & 52 & 40 & 39 & 44 \\
\hline Wesley School & 49 & 46 & 90 & 79 & 83 & 75 & 98 & 85 \\
\hline
\end{tabular}

THIRD GRADE

PERCENT OF STUDENTS AT OR ABOVE GRADE LEVEL ON ITBS

\begin{tabular}{|l|c|c|c|c|c|c|c|c|}
\hline & \multicolumn{2}{|c|}{1977} & \multicolumn{2}{c|}{1978} & \multicolumn{2}{c|}{1979} & \multicolumn{2}{c|}{1980} \\
\hline & $\mathrm{V}$ & $\mathrm{C}$ & $\mathrm{V}$ & $\mathrm{C}$ & $\mathrm{V}$ & $\mathrm{C}$ & $\mathrm{V}$ & $\mathrm{C}$ \\
\hline Control Schools, N=10 & 19 & 26 & 33 & 33 & 32 & 41 & 29 & 46 \\
\hline Wesley School & 14 & 18 & 40 & 49 & 87 & 85 & 88 & 85 \\
\hline
\end{tabular}

Figure 5. ITBS Vocabulary and Comprehension Scores Comparing Wesley to 10 HISD Control Schools 


\section{RIMES}

\begin{tabular}{|c|c|c|c|c|}
\hline $\begin{array}{c}\text { Year of } \\
\text { Implementation }\end{array}$ & $\begin{array}{c}\text { Cost of } \\
\text { Materials }\end{array}$ & Pre-service & In-service & In-class \\
\hline $\begin{array}{c}\text { Firstyear for } \\
\text { K, 1stgrade or } \\
\text { remedial 2nd } \\
\text { grade }\end{array}$ & $\begin{array}{c}\text { Number of } \\
\text { classes }\end{array}$ & $\begin{array}{c}\text { Consultant: } \\
\text { day @ \$300- }\end{array}$ & $\begin{array}{c}\text { Consultant: } \\
1 \text { day @ \$300- } \\
500 \text { (or more) }\end{array}$ & $\begin{array}{c}\text { Consultant: } \\
1 \text { day @ \$300- } \\
500 \text { (or more) }\end{array}$ \\
\hline $\begin{array}{c}\text { Secondyear } \\
\text { with same } \\
\text { grades }\end{array}$ & $\begin{array}{c}\text { Number of } \\
\text { classes }\end{array}$ & On-site coach & On-site coach & On-site coach \\
\hline
\end{tabular}

Figure 6. Estimated Costs

\section{REFERENCES}

Becker, W. C., Engelmann, S., \& Thomas, D. R. (1975a). Teaching I: Classroom management. Chicago: Science Research Associates.

Becker, W. C., Engelmann, S., \& Thomas, D. R. (1975b). Teaching 2: Cognitive learning and instruction. Chicago: Science Research Associates.

Carnine, D., \& Silbert, 1. (1979). Direct instruction reading. Columbus, OH: Merrill.

Grossen, B. (1997). Thirty years of NICHD research: What we know about how children learn to read. Santa Cruz, CA: Center for the Future ofTeaching and Learning. 